\title{
Purification and characterization of human 92-kDa type IV collagenase (gelatinase B)
}

\author{
Dae-Heui Lee ${ }^{1}$ and Kooil Kang ${ }^{1,2}$ \\ 1 Department of Pharmacology, Kosin Medical College, \\ Pusan 602-702, Korea \\ 2 To whom correspondence should be addressed. \\ Accepted 30 August 1996
}

Abbreviation: MMP, matrix metalloproteinase similarities in their protein substrate specificities and the domain organizations of their polypeptide chains (Netzel-Arnett et al., 1993).

In 1972 Harris and Krane described a metalloendopeptidase from human synovium explants that could degrade denatured interstitial collagens. Since its description by Sopata and Dancewicz (Sopata and Dancewicz,1974), human neutrophil gelatinase has been examined by several investigators (Murphy et al., 1980, 1982), and Hibbs et al. (1985) described 92-kDa type IV collagenase from human neutrophils in 1985.

Because of difficulties in isolating the enzyme in sufficient quantity as pure form, very little knowledge has been accumulated on their detailed biochemistry (Docherty et al., 1990).

In 1985 Hibbs et al. isolated and purified neutrophil gelatinase by inducing neutrophils to secrete this enzyme in short-term culture. However, the yield was extremely low: From the starting material of $1.5 \mathrm{~g}$ proteins, they obtained only $2.85 \mathrm{mg}$ of purified enzyme (0.19\% yield).

Tetracycline inhibition of neutrophil-associated collagenolysis has been the focus of a number of investigations (Gabler et al., 1991). Gloub and associates (Gloub et al., 1983, 1984, 1985, 1987) have provided evidence that tetracyclines can inhibit collagenase activity in vitro and in vivo, by binding to $\mathrm{Ca}^{2+}$ and $\mathrm{Zn}^{2+}$. Zucker et al. (1989) described that tetracycline inhibits human $72-\mathrm{kDa}$ type IV collagenase isolated from human small cell lung cancer.

In this report we described a simplified method of isolation of human 92-kDa type IV collagenase from human leukocytes and characterization of this enzyme.

\section{Materials and Methods}

\section{Materials}

Materials used in this work were obtained from the following sources: sodium acetate, aminophenylmercuric acetate (APMA), bovine serum albumin, EDTA, EGTA, tetracycline, Brij 35, N-succinyl-ala-ala-ala-pnitroanilide (SANA), N-succinyl-ala-ala-pro-phe-pnitroanilide (SAPNA), Tris base, and calcium chloride from Sigma Chemical Co., St. Louis, MO. U.S.A.; high molecular weight and low molecular weight electrophoresis calibration kits from Pharmacia, Brussels, Belgium; Ultrogel AcA 54 from LKB,Uppsala, Sweden; Bio-Rex 70, and all reagents for SDS-PAGE from BioRad, Hercules, CA, U.S.A.; Spectrapor dialysis membane from Spectramedical Co, Houston, TX. U.S.A.; PM 10 concentration membrane from Amicon 
Co., Beverly, MA, U.S.A.

\section{Preparation of leukocytes}

Human leukocytes were prepared from fresh blood or from donor blood stored overnight at $4-10^{\circ} \mathrm{C}$ (Kosin Medical Center, Pusan, Korea). Human leukocytes were purified by the method of Kang et al. (1987). Whole blood was centrifuged at $200 \mathrm{~g}$ for $30 \mathrm{~min}$ at $22^{\circ} \mathrm{C}$. Single buffy coat fractions were carefully collected with Pasteur pipette and collected fraction was centrifuged at $300 \mathrm{~g}$ for $25 \mathrm{~min}$ at $22^{\circ} \mathrm{C}$. The leukocytes were isolated from the cell pellets and

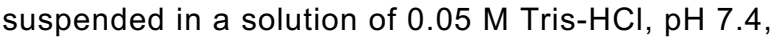
containing $0.2 \mathrm{M} \mathrm{NaCl}, 5 \mathrm{mM} \mathrm{CaCl}_{2}$ and washed three times with the same buffer. Leukocytes were homogenized in $0.5 \mathrm{M}$ Tris- $\mathrm{HCl}, \mathrm{pH} 7.4$, containing $2 \mathrm{M}$ $\mathrm{NaCl}, 0.05 \mathrm{M} \mathrm{CaCl}_{2}$ by Polytron (Kinematica $\mathrm{CH}-6010$, Brinkman Co., Kriens-Luzern, Switzerland) and centrifuged at $32,000 \mathrm{~g}$ for $60 \mathrm{~min}$ at $4^{\circ} \mathrm{C}$. Supernatant was collected and used for further purification.

\section{Gel filtration}

Aliquots of the crude extract were chromatographed at $4^{\circ} \mathrm{C}$ through a $2.5 \times 100 \mathrm{~cm}$ column of Ultrogel AcA 54 equilibrated with $50 \mathrm{mM}$ Tris- $\mathrm{HCl}$ buffer, $\mathrm{pH} 7.3$, containing $0.15 \mathrm{M} \mathrm{NaCl}, 5 \mathrm{mM} \mathrm{CaCl}_{2}$ and $0.1 \%$ Brij 35 . Fractions were assayed for protein and gelatinase. The fractions demonstrating gelatinolytic activity were pooled and diluted 2 fold with $50 \mathrm{mM}$ sodium acetate containing $50 \mathrm{mM}$ Tris- $\mathrm{HCl}, \mathrm{pH} 7.4,2 \mathrm{mM} \mathrm{CaCl}_{2}$ and $0.1 \%$ Brij 35 for ion exchange chromatography.

\section{lon exchange chromatography}

Aliquots of sample purified by gel filtration were applied to a column $(3.0 \times 27 \mathrm{~cm})$ of Bio-Rex 70 which had been previously equilibrated in the $50 \mathrm{mM}$ sodium acetate containing $50 \mathrm{mM}$ Tris- $\mathrm{HCl}, \mathrm{pH} 7.4,2 \mathrm{mM} \mathrm{CaCl}_{2}$ and $0.1 \%$ Brij 35 . The column was washed with the starting buffer until the absorbance at $280 \mathrm{~nm}$ reached baseline, and the bound fraction was eluted with a linear gradient of sodium acetate from $0.05 \mathrm{M}$ to $0.7 \mathrm{M}$. The fractions were assayed for gelatinolytic activity. The fractions containing gelatinolytic activity were pooled and concentrated to one-fourteenth of the original volume by ultrafiltration system with PM 10 membrane. The concentrate was dialyzed against $50 \mathrm{mM}$ sodium acetate containing $50 \mathrm{mM}$ Tris- $\mathrm{HCl}, \mathrm{pH} 7.4,2 \mathrm{mM}$ $\mathrm{CaCl}_{2}$ and $0.1 \%$ Brij 35 .

\section{Gel electrophoresis}

SDS-PAGE was performed using a slab gel apparatus (Hoefer) according to the method of Laemmli (Laemmli, 1970). The gels were stained in $0.1 \%$ Coomassie Brilliant Blue in 25\% methanol, $10 \%$ acetic acid and destained in $25 \%$ methanol, $10 \%$ acetic acid.

\section{Enzyme assay}

The enzyme was activated by incubation with $3 \mathrm{mM}$ of p-aminophenylmercuric acetate(APMA) at $37^{\circ} \mathrm{C}$ for $1 \mathrm{~h}$. Denatured type I collagen was incubated with the activated enzyme for $17 \mathrm{~h}$ at $37^{\circ} \mathrm{C}$. Enzyme activity was identified by SDS-PAGE.

\section{Inhibition of 92-kDa gelatinase activity}

The activated enzyme was preincubated with $20 \mathrm{mM}$ EGTA, $20 \mathrm{mM}$ EDTA and $20 \mathrm{mM}$ tetracycline, respectively, for $30 \mathrm{~min}$ at $37^{\circ} \mathrm{C}$. Denatured type I collagen were incubated with the preincubated enzyme in the presence of $20 \mathrm{mM}$ EGTA, $20 \mathrm{mM}$ EDTA and 20 $\mathrm{mM}$ tetracycline, respectively, for $17 \mathrm{~h}$ at $37^{\circ} \mathrm{C}$. Reaction products were separated on $10 \%$ polyacrylamide gel and enzyme activity was identified.

\section{Results}

\section{Purification of 92-kDa type IV collagenase by Ultrogel AcA 54 chromatography}

Ultrogel AcA 54 gel filtration provided a satisfactory method for the initial separation of the gelatinase from majority of other proteins (Figure 1). The proteins appeared as several peaks and the fractions 42-48 contained gelatinolytic activity (Figure 2). The fraction 51-60 contained a trace of gelatinolytic activity but it also contained elastinolytic activity. The fractions 27-39 contained hemoglobin and other macromolecules which were contained in leukocyte extract. The fractions 60 63 contained elastolytic activity and the fractions 66-69 contained cathepsin G.

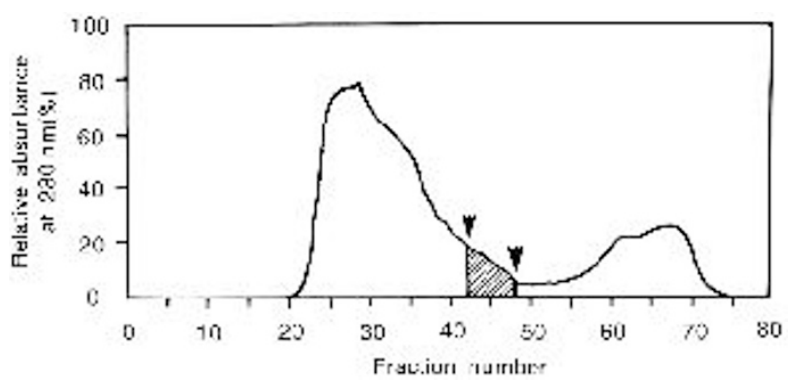

Figure 1. Purification of $92-k D a$ type IV collagenase by Ultrogel AcA 54 chromatography. The column $(2.5 \times 100 \mathrm{~cm})$ was equilibrated with $50 \mathrm{mM}$ Tris- $\mathrm{HCl}$ buffer, $\mathrm{pH} 7.3$, containing $0.15 \mathrm{M}$ of $\mathrm{NaCl}, 5 \mathrm{mM} \mathrm{CaCl}_{2}$ and $0.1 \%$ Brij 35. The sample from leukocyte extract was applied and $8 \mathrm{ml}$ of fractions were collected at a flow rate of $8 \mathrm{ml} / 15 \mathrm{~min}$. All chromatographic procedures were performed at $4^{\circ} \mathrm{C}$. - : protein profile. 
A

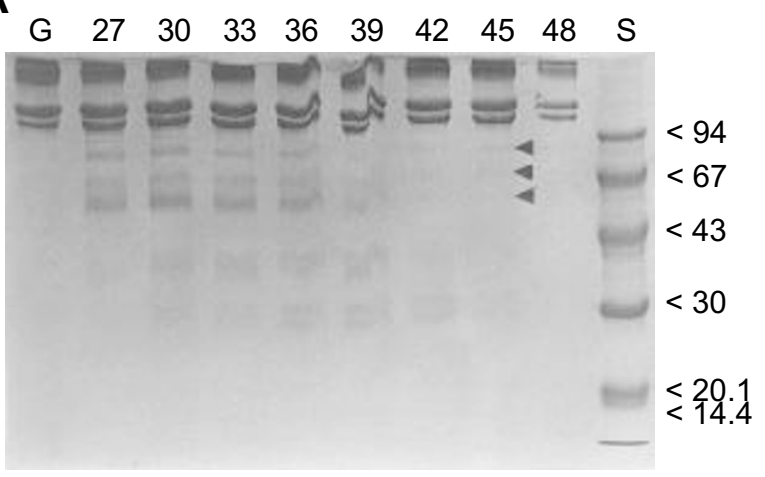

B

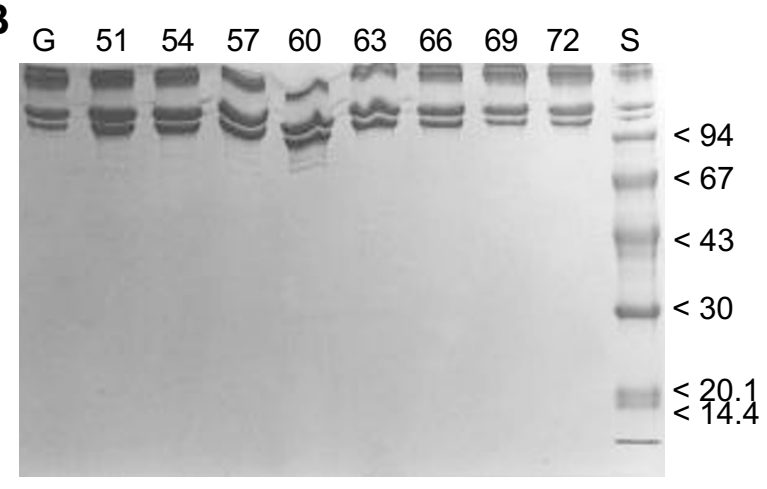

Figure 2. SDS-PAGE of fractions isolated by Ultrogel AcA 54 chromatography. Lane $\mathrm{G}$ : denatured type I collagen; lanes of the fraction 27-72: $45 \mu \mathrm{g}$ of denatured type I collagen were incubated with $70 \mu \mathrm{l}$ of aliquots of sample isolated by Ultrogel AcA 54 chromatography for $17 \mathrm{~h}$ at $25^{\circ} \mathrm{C}$. Reaction products were separated on $10 \%$ polyacrylamide gel (panels A and B). The positions of degradation products of collagen are marked. Lane $\mathrm{S}$, molecular mass markers were run on a separate tract of the same gel and are indicated.

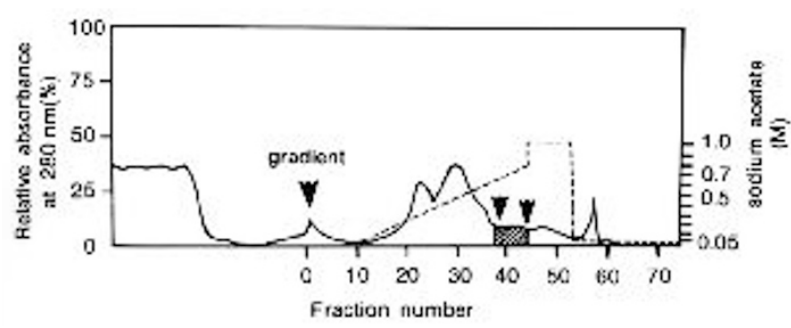

Figure 3. Purification of $92-k D a$ type IV collagenase by Bio-Rex 70 ion exchange chromatography. The column $(2.5 \times 100 \mathrm{~cm})$ was equilibrated with $50 \mathrm{mM}$ sodium acetate containing $50 \mathrm{mM}$ Tris- $\mathrm{HCl}$, pH 7.4, $2 \mathrm{mM} \mathrm{CaCl}_{2}$ and0.1\% Brij 35. After sample (the gelatinolytic enzyme partially purified by gel chromatography on Ultrogel AcA 54) was applied, the column was washed with the same buffer until the absorbance at $280 \mathrm{~nm}$ reached base-line. Elution was performed at $\mathrm{pH} 7.4$ with linear gradient of sodium acetate from $0.05 \mathrm{M}$ to $0.7 \mathrm{M}$. $7 \mathrm{ml}$ fractions were collected at a flow rate of $7 \mathrm{ml} / 5 \mathrm{~min}$.

\section{Purification of 92-kDa type IV collagenase by Bio-Rex 70 ion exchange chromatography}

Gelatinolytic activity was further purified by Bio-Rex 70 ion exchange chromatography. From this chromatography, several different proteins were separated (Figure 3 ). The gelatinolytic activity was seen in the fraction number 32-44 (Figure 4), at sodium acetate concentration between $0.5 \mathrm{M}$ and $0.7 \mathrm{M}$. The fractions 38-44 were pooled, concentrated and dialyzed against $50 \mathrm{mM}$ sodium acetate containing $50 \mathrm{mM}$ Tris- $\mathrm{HCl}, \mathrm{pH}$ $7.4,2 \mathrm{mM} \mathrm{CaCl} 2$ and $0.1 \%$ Brij 35. The volume and protein concentration of the dialysate was $3.5 \mathrm{ml}$ and $1.1 \mathrm{mg} / \mathrm{ml}$, respectively.

\section{Molecular weight determination and gelatinolytic activity of purified enzyme on the SDS-PAGE}

SDS-PAGE of the purified enzyme and degradation

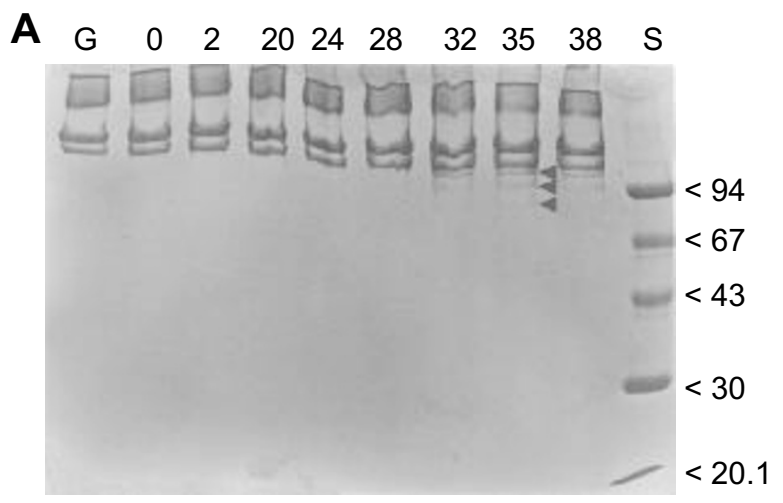

$\begin{array}{lllllllllll}\text { B } & \text { G } & 41 & 44 & 47 & 50 & 53 & 56 & 58 & 61 & \mathrm{~S}\end{array}$

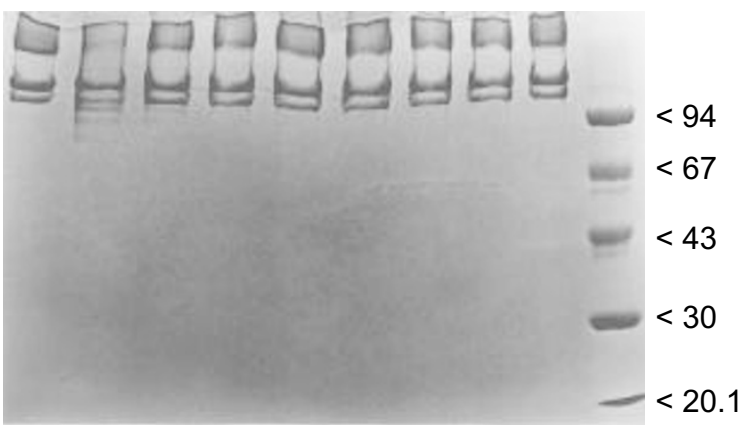

Figure 4. Enzyme activity of fractions isolated by Bio-Rex 70 ion exchange chromatography. Lane G: denatured type I collagen; lanes of the fraction 0-61: $73.5 \mu \mathrm{g}$ of denatured type I collagen were incubated with $70 \mu \mathrm{l}$ of aliquots of sample isolated by Bio-Rex 70 ion exchange chromatography for $17 \mathrm{~h}$ at $37^{\circ} \mathrm{C}$. Reaction products were separated on $10 \%$ SDS-polyacrylamide gel (panels A and B). The positions of degradation products were marked. Lane $\mathrm{S}$, molecular mass markers were run on a separate tract of the same gel and are indicated. 
product was carried out and the results are shown in Figure 5. The purified gelatinase showed a single band with an apparent molecular weight of 92-kDa (lane 2). Lane 3 showed that denatured type I collagens (gelatins) with molecular weight of 124,000 and 112,000 and the fragments after hydrolysis by gelatinase with molecular weight of $100,000,94,000$, 92,000 and 60,000 .

\section{Inhibition of 92-kDa gelatinase activity}

As shown in Figure 6, lanes 3 and 4 showed that denatured type I collagens (gelatins) with molecular weight of 124,000 and 112,000 and the fragments after hydrolysis by gelatinase with molecular weight of $100,000,94,000,92,000$ and 75,000. Lanes 5 and 6 showed that denatured type I collagens with molecular weights of 124,000 and 112,000 and the fragments after hydrolysis by gelatinase with molecular weight of 92,000 . But there was no fragments after hydrolysis by gelatinase in the lane 7.92-kDa gelatinolytic activity was inhibited markedly by the metal chelators, EGTA, EDTA, and tetracycline. Among these inhibitors, tetracycline was the strongest inhibitor of the $92-\mathrm{kDa}$ gelatinase.

\section{Discussion}

In this study we have isolated $3.85 \mathrm{mg}$ of $92-\mathrm{kDa}$ type IV collagenase from $132 \mathrm{mg}$ of leukocyte extract $(2.9 \%$ yield), by a combination of Ultrogel AcA 54 gel filtration and Bio-Rex 70 ion exchange chromatographies. Purified enzyme showed a single band on SDS-PAGE with a molecular mass of 92-kDa. Considering previous data on two step chromatography techniques for the same enzyme (Hibbs et al. 1985), the presently described two step purification method is much simpler and more convenient. The purification of metalloproteinases from human polymorphonuclear neutrophil leukocytes is technically difficult for two main reasons: (a) the metalloproteinase contents are relatively low, and (b) both enzymes are degraded by the serine proteinases, which are present in large amounts in the azurophil granules (Murphy et al., 1980). It has been calculated that $1 \times 10^{9}$ neutrphils contain approx. $0.2 \mathrm{mg}$ of collagenase and $0.1 \mathrm{mg}$ of gelatinase, in contrast to $4 \mathrm{mg}$ of elastase and $4 \mathrm{mg}$ of cathepsin G (Murphy et al., 1982). We simplified the purification procedure of 92-kDa type IV collagenase to minimize the loss of enzyme during the multistep preparation. Therefore this method of preparation is very rapid and suitable for purification of enzyme from large quantities of starting material.

To investgate the biological and enzymatic characteristics of the purified enzyme, inhibition study of gelatinolytic activity of the enzyme by metal chelators

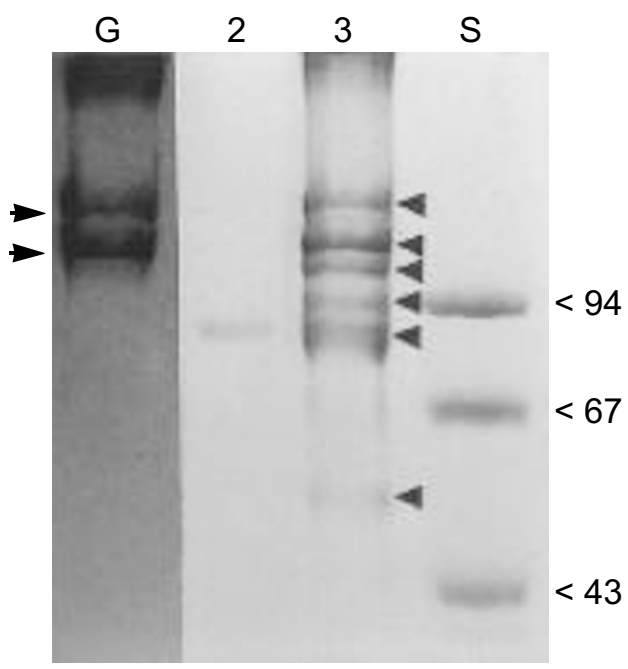

Figure 5. Analysis of purified enzyme and its gelatinolytic activity on the SDS-PAGE. Lane G: denatured type I collagen; lane 2: purified enzyme; lane 3: $73.8 \mu \mathrm{g}$ of denatured type I collagen was incubated with $200 \mu \mathrm{g}$ of purified enzyme for $4 \mathrm{~h}$ at $37^{\circ} \mathrm{C}$. Reaction products were separated on a $10 \%$ SDS-polyacrylamide gel. Molecular mass markers were run on a separate tract of the same gel and are indicated.

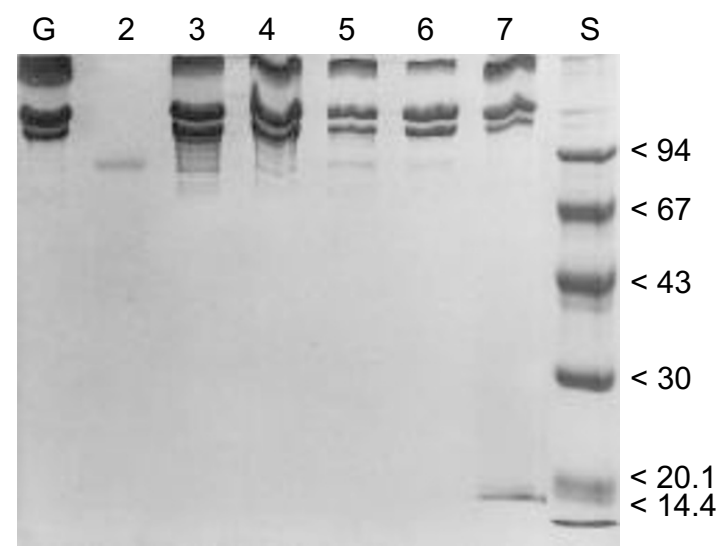

Figure 6. Inhibition of 92-kDa type IV collagenase by EGTA, EDTA and tetracycline. Lane $\mathrm{G}, 14.7 \mu \mathrm{g}$ of denatured type I collagen, lane 2: purified enzyme; lane $3 \sim 4,14.7$ $\mu \mathrm{g}$ of denatured type I collagen were incubated with $2.2 \mu \mathrm{g}$ of purified enzyme for $17 \mathrm{~h}$ at $37^{\circ} \mathrm{C}$; lane $5 \sim 7: 14.7 \mu \mathrm{g}$ of denatured type I collagen were incubated with $2.2 \mu \mathrm{g}$ of purified enzyme in the presence of $20 \mathrm{mM}$ EGTA (lane 5), $20 \mathrm{mM}$ EDTA (lane 6) and $20 \mathrm{mM}$ tetracycline (lane 7), respectively, for $17 \mathrm{~h}$ at $37^{\circ} \mathrm{C}$. Reaction products were separated on a $10 \%$ SDS-polyacrylamide gel. Molecular mass markers were run on a separate tract of the same gel and are indicated.

was performed. As can be seen in Figure 6, gelatinolytic activity of the purified enzyme was inhibited markedly by $20 \mathrm{mM}$ EGTA, $20 \mathrm{mM}$ EDTA and $20 \mathrm{mM}$ tetracycline, respectively. The reason for these inhibition could be that the active site zinc atom had been chelated and released from the catalytic domain 
of the enzyme, resulting in the loss of hydrolytic activity. In good agreement with the report by Zucker et al., (1989), the gelatinolytic activity of type IV collagenase was more strongly inhibited by tetracycline than EGTA and EDTA.

\section{Acknowledgement}

This work was supported by fund from the Basic Medicine Research Laboratory in Kosin Medical College, Pusan, Korea.

\section{References}

Docherty, A. J. P. and Murphy, G. (1990) The tissue metalloproteinase family and the inhibitor TIMP: a study using cDNAs and recombinant proteins. Ann. Rheu. Dis. 49: 469-479

Gabler, W. L. and Creamer, H. R. (1991) Suppression of human neutrophil function by tetracyclines. J. Periodont. Res. 26: 52-58

Gloub, L. M., Lee, H. M., Lehrer, G., Nemiroff, A., McNamara, T. F., Kaplan, R. and Ramamurthy, N. S. (1983) Minocycline reduces gingival collagenolytic activity during diabetes: preliminary observation and a proposed new mechanism of action. $J$. Periodont. Res. 18: 516-526

Gloub, L. M., Ramamurthy, N. and McNamara, T. F. (1984) Tetra-cyclines inhibit tissue collagenase activity. J. Periodont. Res. 19: 651-655

Gloub, L. M., Wolff, M. and Lee, H. M. (1985) Further evidence that tetracyclines inhibit collagenase activity in humn crevicular fluid and from other mammalian source. J. Periodont. Res. 20: 12-23

Golub, L. M., McNamara, T. F., Angelo, G. D., Greenwald, R. A. and Ramamurthy, N. S. (1987) A non-antibacterial chemically-modified tetracycline inhibits mammalian collagenase activity. J. Dent. Res. 66: 1310-1314
Harris, E. D. and Krane, S. M. (1972) An endopeptidase from rheumatoid synovial tissue culture. Biochim. Biophys. Acta 258: 566-576

Hibbs, M. S., Hasty, K. A., Seyer, J. M., Kang, A. H. and Mainardi, C. L. (1985) Biochemical and immunological characterization of the secreted forms of human neutrophil gelatinase. J. Biol.Chem. 260: 2493-2500

Kang, K., Jeong, H. Y. and Ghim, S.-Y. (1987) Simultaneous separation of pure neutrophils and lymphocytes from normal human blood by step gradient centrifugation. Korean J. Immunol. 9: 27-31

Laemmli, U. K. (1970) Cleavage of structural proteins during the assembly of the head of bacteriophage T4. Nature 227: 680-685

Murphy, G., Bretz, U., Baggiolini, M. and Reynolds, J. J. (1980) The latent collagenase and gelatinase of human polymorphonuclear neutrophil leukocytes. Biochem. J. 192: 517-525

Murphy, G., Reynolds, J. J., Bretz, U. and Baggiolini, M. (1982) Partial purification of collagenase and gelatinase from human polymorpho-nuclear leukocytes. Biochem. J. 203: $209-221$

Netzel-Arnett, S., Sang, Q., More, W. G. I., Navre, M., Birkedal Hansen, H. and VanWart H. E. (1993) Comparative sequence specificities of human 72- and 92-kDa gelatinases (type IV collagenases) and pump (matrilysin). Biochemistry 32: 6427-6432

Sopata, I. and Dancewicz, A. M. (1974) Presence of gelatin specific proteinase and its latent form in human leukocytes. Biochim. Biophys. Acta 370: 510-523

Woessner, J. F. (1991) Matrix metalloproteinases and their inhibitors in connective tissue remodeling. FASEB J. 5: 2145-2154

Zucker, S., Wieman, J., Lysik, R. M., Imhof, B., Nagase, H., Ramamurthy, N., Liotta, L. A. and Golub, L. M. (1989) Gelatin-degrading type IV collagenase isolated from human small cell lung cancer. Invasion Metastasis 9: 167-181 